\title{
Assessment of Responses of Common Carp, Cyprinus carpio, Exposed to Sub-Lethal Concentrations of Lead, by Molecular and Mucosal Biomarkers
}

\author{
Fakhriyeh Omidi $^{1, *}$ (D), Hojatollah Jafaryan ${ }^{1}$, Rahman Patimar $^{1}$, Mohammad Harsij ${ }^{1}$, \\ Hamed Paknejad²
}

${ }^{1}$ University of Gonbad Kavous, Faculty of of Natural Resources, Department of Fisheries, , Gonbad Kavous, Iran.

${ }^{2}$ Gorgan University of Agricultural Sciences and Natural Resources, Faculty of of Natural Resources, Department of Fisheries, Gorgan, Iran.

How to cite

Omidi, F., Jafaryan, H., Patimar, R., Harsij, M., Paknejad, H. (2022). Assessment of Responses of Common Carp, Cyprinus carpio, Exposed to SubLethal Concentrations of Lead, by Molecular and Mucosal Biomarkers. Genetics of Aquatic Organisms, 6(1), GA448. http://doi.org/10.4194/GA448

\section{Article History}

Received 09 August 2021

Accepted 08 October 2021

First Online 11 October 2021

\section{Corresponding Author}

Tel.: -

E-mail: fakhriyeh.omidi90@gmail.com

\section{Keywords}

Lead contamination

Cyprinus carpio

Protein pattern

hsp70 gene

Mucosal indicators

\begin{abstract}
Heavy metals are one of the most persistent pollutants in waters, and molecular biomarkers as bioindicators could uncover early warning signals of stress suffered by organisms exposed to these pollutants. This research was conducted to explore the impact of lead contaminant on expression levels of hsp70 gene as well as protein pattern and innate immune indicators of skin mucus in Common carp as a biological model. The fish were exposed to different concentrations of $\mathrm{Pb}\left(\mathrm{NO}_{3}\right)_{2}$ as a source of lead $(0,7.875,15.75$, and $31.5 \mathrm{mg} / \mathrm{L}$ of lead) for 14 days. After the completion of the experiment, the liver and gill tissue plus mucus samples were collected from the fish. Next, the effects of exposure to sublethal doses of lead were investigated on expression levels of hsp70 gene, protein pattern, and innate immune indicators of skin mucus. The results indicated that the expression level of hsp70 gene significantly increased (at $7.5 \%$ \& $30 \%$ LC50) in the liver tissue compared to the control group $(\mathrm{P}<0.05)$. The protein pattern of treatment samples was different from that of the control group. Also, in the mucus innate immune parameters, the levels of alkaline phosphatase increased significantly at high concentrations of lead contamination in comparison with the control group $(P<0.05)$. The protein levels first revealed an ascending trend $(P<0.05)$, and then a descending trend (at 30\% LC50), though it was not a significant downward trend compared with the control group $(P>0.05)$. The results suggested that these physiological indicators in Cyprinus carpio could be used as molecular and mucosal biomarkers for ecotoxicological studies.
\end{abstract}

\section{Introduction}

Water systems may be widely contaminated by toxic metals released from household, industrial, and other human activities. Toxic metal pollution may have detrimental effects on ecological balance and biodiversity of marine ecosystems (Vinodhini \& Narayanan, 2008). Among metals, lead is of particular concern since it is extremely toxic to aquatic creatures at ecologically related levels (Zhang et al., 2008).
Evaluation of the expression levels of different genes as molecular biomarkers under different exposure conditions has prompted new studies (Head et al., 2012). Indeed, molecular changes as the first measurable changes can provide helpful information to understand the effects of environmental stress on aquatic life (Rose et al., 2006). Among the investigated factors, heat shock protein expression level is a suitable biomarker in environmental toxicology studies (Tedeschi et al., 2015; Cantinha et al., 2017). 
Stress indices in mucus are increasingly used as an indicator (mucosal biomarkers) for assessing the impact of sub-lethal stressors on fish. A mucous layer covers the fish skin which constantly changes. The mucus serves as a physical barrier between aquatic medium and fish; it has advanced diverse innate immune factors, such as proteases, immunoglobulins, lysozyme, proteolytic enzymes, lectins, as well as other antibacterial peptides and proteins (Subramanian et al., 2007). Studies have reported that stress indices in skin mucus change in reaction to physical, environmental, and microbial stresses (Ellis, 2001; Chong et al., 2006; Omidi et al., 2020).

Fish are largely used to assess the quality of the aquatic environment and can be used as an environmental contaminant bioindicator (Dautremepuits et al., 2004). The family Cyprinidae are freshwater fish throughout the world, extensively used as a fish model in the study of evolutionary biology. Cyprinus carpio is the common species of the family Cyprinidae. It is an important commercial species around the universe with an adaptive reaction to environmental pollution (Heidary et al., 2016).

The study about impact of heavy metals on molecular and mucosal biomarkers has been insufficiently conducted to date. Thus, the aim of this study is to investigate the effect of lead contaminant on expression levels of hsp70 gene as well as protein pattern and innate immune indicators of skin mucus in Common carp as a biological model.

\section{Materials and Methods}

\section{Fish Husbandry and Maintenance}

About 400 pieces of Common carp were obtained from aquaculture farms with a mean weight of $20 \pm 3.16$ g. The fish were kept in aquaria (80- L) for two weeks under laboratory conditions and fed twice a day with commercial food of Common carp at the limit $2 \%$ body weight for adaptation. During the adaptation and experimentation period, the fish were maintained a 12 $\mathrm{h}$ light and $12 \mathrm{~h}$ dark cycle.

\section{Determination of LC50 (96-h)}

LC50 determination experiment was carried out at eight concentrations for 96 hours. The fish were exposed to concentrations of $\mathrm{Pb}\left(\mathrm{NO}_{3}\right)_{2}$ as a source of lead. Specifically, the effective concentrations of lead in the determined concentrations were $0,1,10,20,40,80$, 160 , and $320 \mathrm{mg} / \mathrm{L}$ lead (molar mass of lead (II) nitrate $=331.2 \mathrm{~g} / \mathrm{mol}$, molar mass of Lead=207.2 g/mol). Three replicates were taken for each concentration, with the random distribution of seven pieces of fish in each glass aquarium of $80 \mathrm{~L}$. The duration of the lethal test was 96 hours and mortality of fish was recorded daily at these concentrations. Then, Probit software was employed for measuring LC50 (96-h).

\section{Sub-lethal Experiment}

The experiment was performed for 14 days at concentrations of $0,7.5,15$, and $30 \%$ of LC50 lead (II) nitrate. The effective concentration of lead in the determined concentrations of $\mathrm{Pb}\left(\mathrm{NO}_{3}\right)_{2}$ were $0,7.875$, 15.75 , and $31.5 \mathrm{mg} / \mathrm{L}$ of lead (three replicates for each concentration). It was followed by random division of the fish in aquaria (10 fish per aquarium), which were nourished twice per day with commercial food of Common carp at $2 \%$ body weight. The experimental water and lead in the water were changed daily. The parameters of water quality during the experiment were as follows: $\mathrm{pH}$, temperature, dissolved oxygen levels above $6 \mathrm{mg} / \mathrm{L}$, and nitrite below $0.05 \mathrm{mg} / \mathrm{L}$. Animals were starved for $24 \mathrm{~h}$ before sampling.

\section{Molecular Analysis}

\section{Sample Provision}

At the end of the experiment, the sampling steps were conducted in an ethically and professionally. We randomly selected three fish pieces from each aquarium. Clove powder was used for anesthesia, and then the tissues of the liver and gill were separated. They were instantly placed in liquid $\mathrm{N}$ and stockpiled at $-80^{\circ} \mathrm{C}$ until RNA extraction.

\section{Extraction of RNA and cDNA Synthesis}

For extracting RNA, after homogenizing 50-100 mg of gill and liver tissues in $1.0 \mathrm{~mL}$ RNAxPlus reagent (Sinaclon; Iran), they were exposed to ambient temperature for 15 minutes. The approach prescribed by Panigrahi et al. (2011) was followed for conducting other stages of RNA extraction. The spectrophotometer was used for investigating the RNA amount at 260/280 $\mathrm{nm}$. The RNA quality was specified through electrophoresis on a $1.5 \%$ agarose gel stained with ethidium bromide. Genet Bio cDNA synthesis kit (Korea) for real-time PCR was used for synthesizing the firststrand cDNAs in accordance with manufacturer's instructions and based on a combination of oligo-dt as a primer. RT-PCR reactions were conducted three times based on a standard protocol [primary denaturation for $10 \mathrm{~min}$ at $95^{\circ} \mathrm{C}$ in 40 cycles, extension, and annealing at $95{ }^{\circ} \mathrm{C}$ for $15 \mathrm{~s}, 72{ }^{\circ} \mathrm{C}$ for $15 \mathrm{~s}$, and $56^{\circ} \mathrm{C}$ for $30 \mathrm{~s}$ ].

\section{Primer Design and Quantitative RT-PCR}

The qPCR primers for hsp70 and b-actine were designed based on past studies (Ouellet et al.,2013) (Table 1). Standard curve analysis was used for determining the performance of PCR and relative mRNA expression of hsp70 with serial dilution of cDNA (5 dilutions), which was explained by Miandare et al. (2013). The housekeeping gene was b-actine. 
Table 1. Primer pairs used for quantitative mRNA expression

\begin{tabular}{lccc}
\hline Gen & Operation & Particular Primers (5'-3') & Efficiency (\%) \\
\hline -actin & Internal standard & aGGGTATGGAGTCTTGCGGTA & 92.7 \\
& & bACAGGTCCTTACGGATGTCG & \\
hsp-70 & Protein folding and conservation & aTCATGGGAGACACATCTGGA & 92.34 \\
& & bAGGTCTGGGTCTGTTTGGTG & \\
\hline
\end{tabular}

${ }^{\text {aforward primer, }}{ }^{\mathrm{b}}$ reverse primer

An iCycler (Bio-Rad) with Fermentas Maxima SYBR Green qPCR Master Mix with the gene-specific primers was used for conducting Rt-PCR analysis. The rt-PCR analyses were conducted using standard protocol explained by Miandare et al. (2013). The standard curves were created from dilution series of cDNA (5 dilutions from $1 / 10$ to $1 / 200)$. The PCR performance was determined by the formula: $E \%=\left(10^{1 / \text { slope }}-1\right) \times$ 100 (Radonic et al 2004). The standard curve and $2^{-\Delta \Delta C T}$ method were used for determining the fold change in the relative mRNA expression of hsp70 (Livak \& Schmittgen, 2001). The iQ5 optical system software 2.0 (Bio- Rad) was used for data analysis.

\section{Fish Mucus Samples and Sample Analysis}

\section{Mucus Collection}

The approach described by Ross et al. (2000) was used for mucus collection, which was collected from five Common carp per aquarium, with some slight modifications. Packs with $10 \mathrm{ml}$ of $50 \mathrm{mM} \mathrm{NaCl}$ were used for placing the fish. The fish were taken out after 1 minute, and released to the aquaria. We poured the mucus samples into $15 \mathrm{ml}$ sterile centrifuge tubes. They were centrifuged $(1500 \mathrm{~g})$ at $4{ }^{\circ} \mathrm{C}$ for $10 \mathrm{~min}$. The gathered skin mucus was immediately frozen so that bacterial contamination would be prevented. Then, the samples were lyophilized and stockpiled at $-80^{\circ} \mathrm{C}$.

\section{Determination of Soluble Protein Concentration, Alkaline Phosphatase, and Lysozyme Activity}

The approach proposed by Lowry et al. (1951) was employed for determining the protein level of the samples, where serum albumin (BSA, Sigma) was applied as the standard. The commercial kits (Pars Azmon, Iran) and spectrophotometer (405 nm) were employed to determine alkaline phosphatase activity. Also, a turbidimetric test (Subramanian et al., 2007) and spectrophotometer were used to specify lysozyme activity. Shortly, Micrococcus lysodeikticus was held in $50 \mathrm{cc}$ of sodium acetate buffer $(17 \mu$ l of glacial acetic acid per $100 \mathrm{cc}$ of water, $139 \mathrm{mg}$ of sodium acetate, $\mathrm{pH}$ 5.5). Specifically, $250 \mu \mathrm{l}$ of mucus samples was then combined with $1.25 \mathrm{~mL}$ of bacterial suspension, and the sample absorbance reduction was observed for $10 \mathrm{~min}$ at $450 \mathrm{~nm}$. A unit of lysozyme activity was described as the amount of enzyme resulting in absorbance reduction of 0.001 per minute.

\section{SDS-PAGE}

Sodium dodecyl sulphate-polyacrylamide gel electrophoresis (SDS-PAGE) was used for examining the protein pattern of the aqueous extract of skin mucus, in accordance with the approach explained by Laemmli (1970). The migration buffer contained $192 \mathrm{mM}$ glycine (pH 8.5) and $25 \mathrm{mM}$ Tris. The samples were combined with sample buffer composed of $0.1 \%$ SDS, $0.01 \mathrm{M}$ Trisglycine buffer ( $\mathrm{pH}$ 6.8), 20\% glycerol, and 1\% 2-bmercaptoethanol. It was then warmed for $4 \mathrm{~min}$ at 100 ${ }^{\circ} \mathrm{C}$, centrifuged at $1000 \mathrm{~g}$ for $3 \mathrm{~min}$ (2K15 Sigma), and used on the gel, running with a continuous current [50 $\mathrm{mV}(15 \%)$ and $30 \mathrm{mV}(7 \%)]$. Then, the gel was stained with Coomassie Brilliant Blue $\mathrm{G}$, while trypsin inhibitor (20.1 kDa), Lactalbumin (14.4 kDa), carbonic anhydrase (30 kDa), phosphorylase b (94 kDa), and albumin (67 $\mathrm{kDa})$ were utilized as molecular weight markers (Pharmacia).

\section{Data Analysis}

The data normality was surveyed. Data were analyzed by Duncan test and one-way ANOVA (confidence level 95\%) using R-3.5.2 Software.

\section{Results}

\section{Assessment of Hsp70 Gene Expression in Liver and Gill}

The impacts of varying lead levels on the expression of hsp70 in the gill and liver of Common carp were analyzed (Figures 1 and 2). With elevation of lead concentration, hsp70 gene expression levels in the gill did not indicate any significant difference in comparison with the control group $(P>0.05)$, while hsp70 gene expression levels in fish liver grew with increasing the lead concentration (at 7.5\% \& 30\% LC50) in comparison with the control group $(\mathrm{P}<0.05)$.

\section{Protein Pattern Assay}

The protein profiles of the treated samples and control samples were significantly different (Figures 3 and 4). As revealed by protein pattern results, changes occurred in the treated groups in terms of intensity of the protein bands (in the band of $25 \mathrm{kDa}$ ). The results demonstrated a new band in treated groups while the control group did not show it (between 17 and $25 \mathrm{kDa}$ ). 


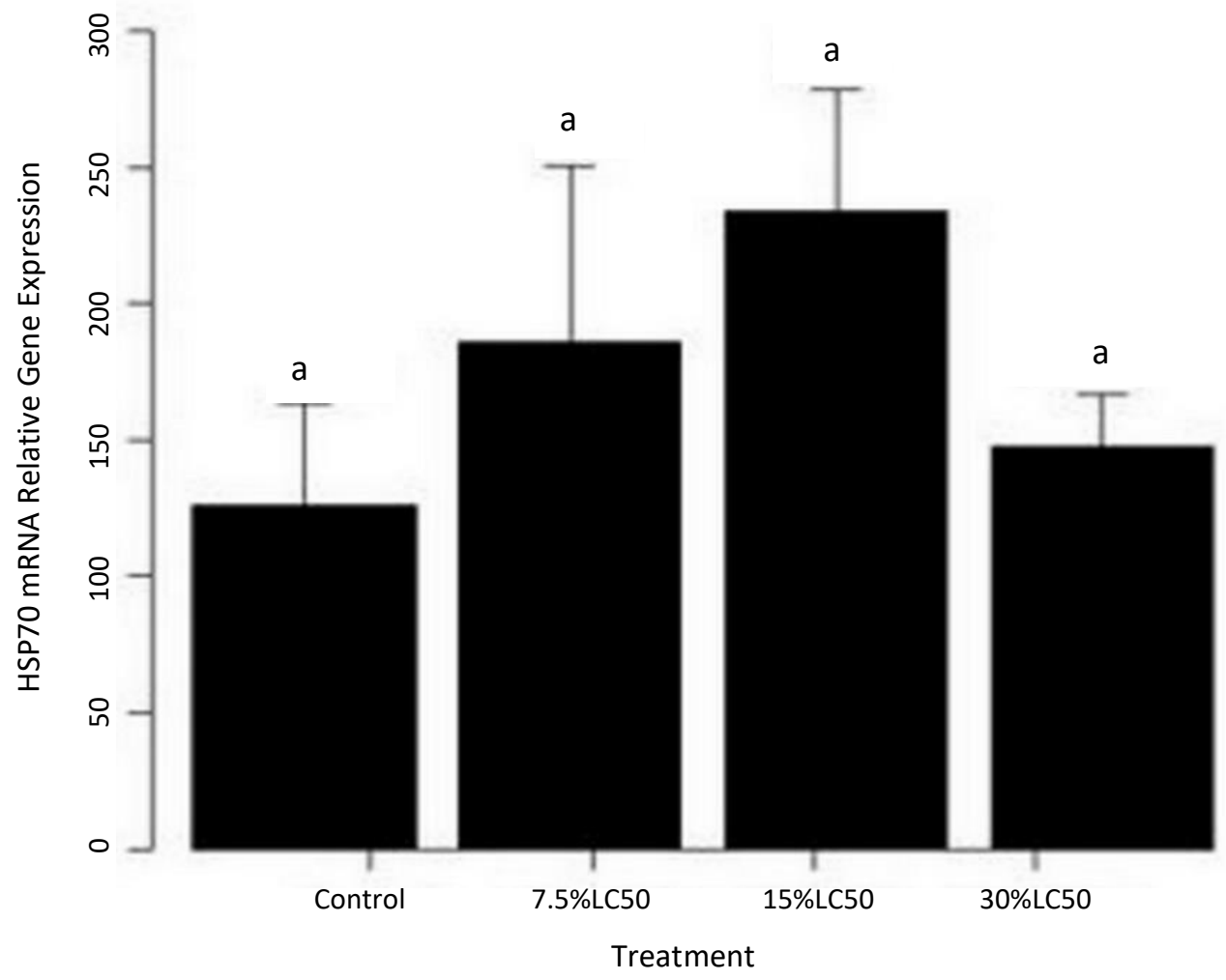

Figure 1. The expression of gene hsp70 in the gill of Cyprinus carpio exposed to sub-lethal concentrations of lead; Values are expressed as the mean \pm S.D. The bars with different letters show significant differences between treatments $(P<0.05)$.

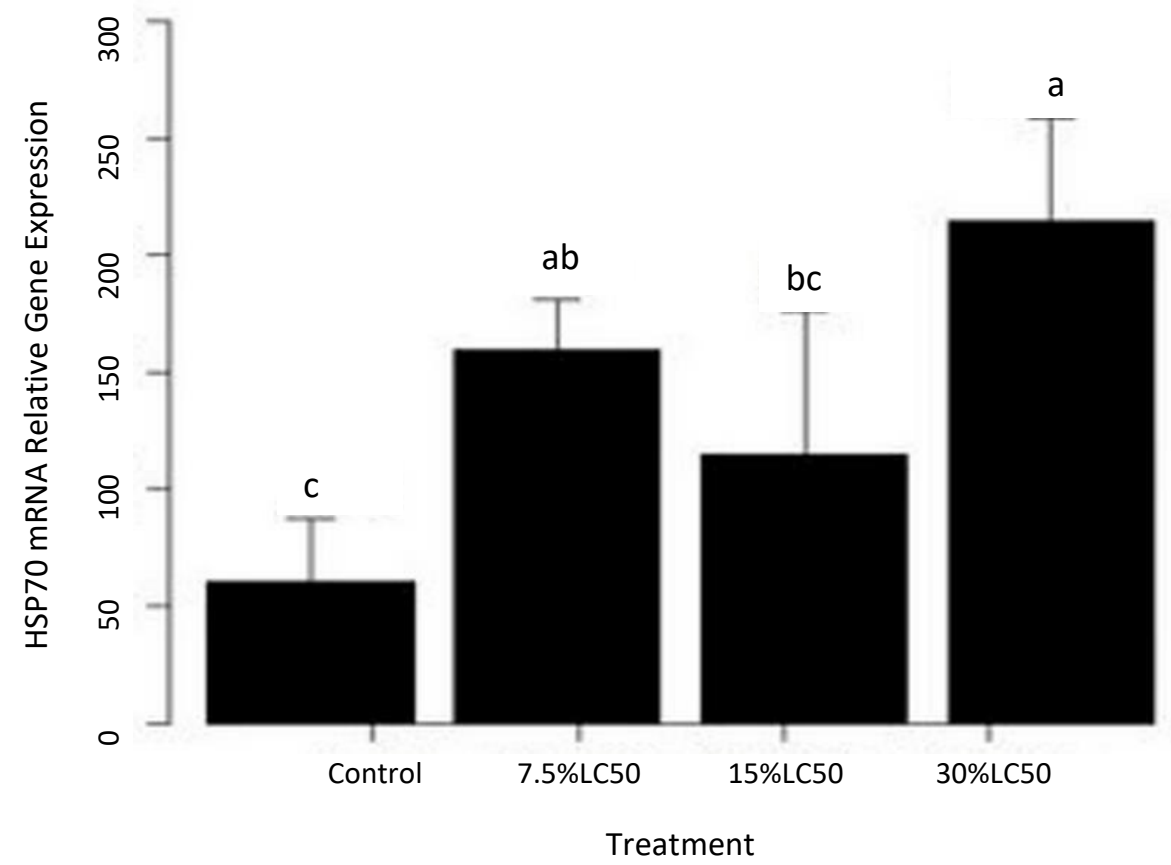

Figure 2. The expression of gene hsp70 in the liver of Cyprinus carpio exposed to sub-lethal concentrations of lead; Values are expressed as the mean \pm S.D. The bars with different letters indicate significant differences between treatments $(P<0.05)$. 


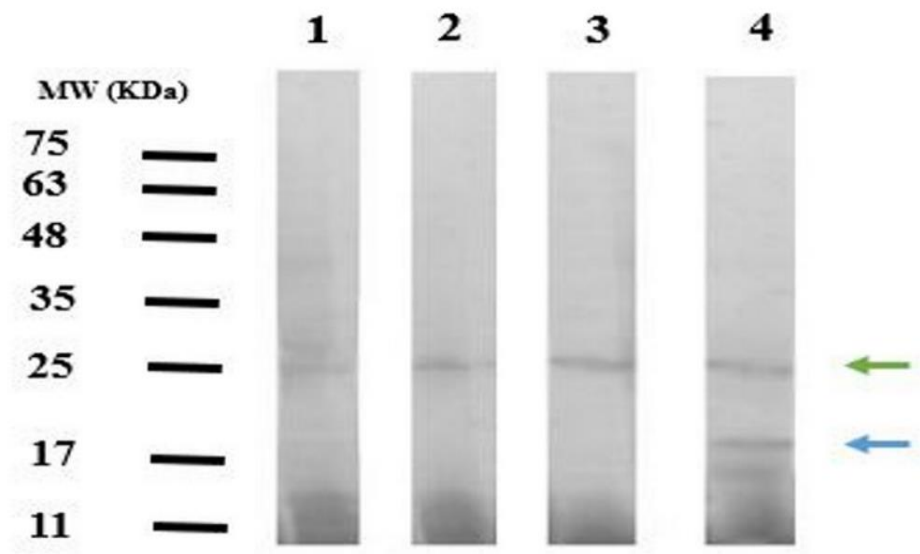

Figure 3. Assessment of skin mucus protein pattern by SDS-PAGE; Bands with enhanced intensity are indicated by green arrows; the blue arrow indicates a new band; Line 1: Control, Line 2: 7.5\% LC50, Line 3: 15\% LC50, Line 4: 30\% LC50.
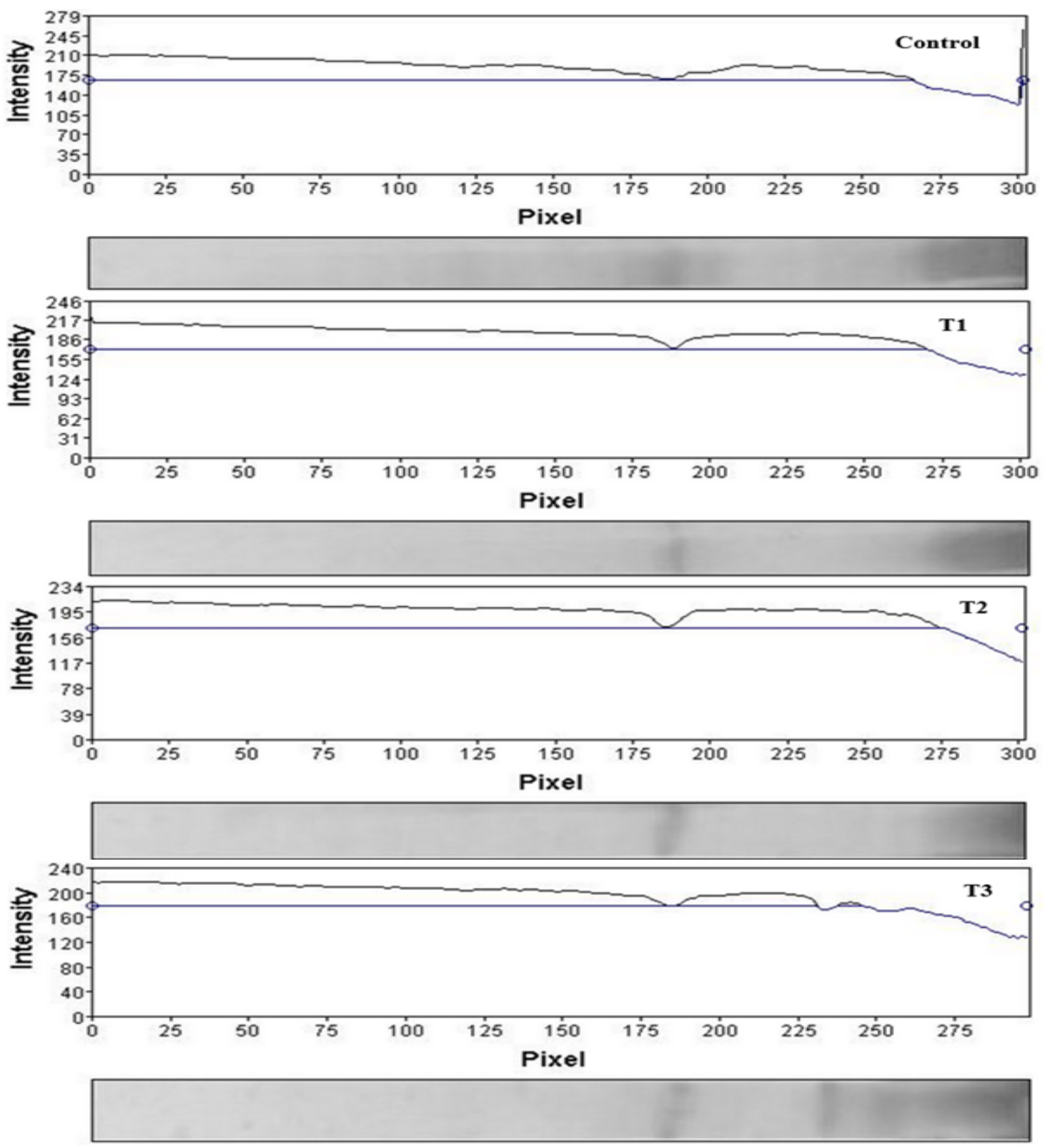

Figure 4. The impact of varying lead concentrations on the pattern of skin mucus protein bands in Cyprinus carpio by gel analyzer software; Control: 0\%LC50, T1: 7.5\% LC50, T2: 15\% LC50, T3: 30\% LC50. 


\section{Measurement of Mucus Safety Parameters}

The mucus safety parameters in Common carp exposed to sub-lethal concentrations of lead were measured (Figure 5). Increasing lead levels significantly altered alkaline phosphatase and protein levels in comparison with the control group $(P<0.05)$, only excepting lysozyme levels $(P>0.05)$. With elevation of lead concentration, protein levels first showed an upward trend, then a descending trend (at 30\% LC50), but it was not a significant diminishing trend in comparison with the control group. Finally, alkaline phosphatase levels increased significantly at high concentrations of lead contamination in comparison to the control group.

\section{Discussion}

The current work explored the impact of lead contaminant on the relative expression of hsp70 gene as well as protein pattern and safety parameters of skin mucus in Common carp. Here, protein pattern changes in mucus of Common carp exposed to varying lead concentrations were demonstrated using SDSpolyacrylamide gel electrophoresis (SDS- Page). The results revealed that there are different protein bands in the protein pattern of Common carp. The protein band intensity, in the $25 \mathrm{kDa}$ range, increased in the treated groups. There was a new band within 17 to 25 $\mathrm{kDa}$, while it was not observed in the control group. The difference in the protein pattern across living creatures can be because of external and internal conditions. The protein profile of mucus has been reported for many species (Lortal et al., 1997; Ebran et al., 1999; Fagan et al., 2003; Subramanian et al., 2008; Khattab et al., 2014). Among the sparse studies on the effect of heavy metals on the protein pattern of fish mucus, recently Omidi et al. (2020) reported a change in the protein pattern of Neogobius melanostomus skin mucus under the influence of heavy metals, using SDS- Page. It was consistent with the results of the present study concerning the effect of lead contamination on the protein pattern of Common carp mucus.

The sample total protein reflects the amount of secretion or the present mucus levels (Yokoyama et al., 2006). Mucus is produced by goblet cells (Guardiola et al., 2015). With readiness of mucosal secretions, these cells release their contents to the fish skin surface. Meanwhile, environmental changes influence the amount of goblet cells in the epidermis (Iger et al., 1994). Fish mucus protein levels in reaction to changes in body physiology and environmental conditions have been reported in many studies (Fagan et al., 2003; Pottinger\& Pickering, 1985; Timalata et al., 2015). Also, in our work, the amount of mucus protein in the Common carp increased in comparison to the control group under the influence of varying concentrations of lead, which concurs with the findings of Omidi et al. (2020).
There are many mucus enzymes in the skin mucus with important functions (Iger et al., 1994; Ebran et al., 1999). Alkaline phosphatase is an antibacterial factor in mucus, which grows in the mucus of fish after exposure to environmental stressors (Sheikhzadeh et al., 2012). In this work, the lysozyme enzyme levels did not show any significant differences at varying lead concentrations; however, the alkaline phosphatase enzyme levels increased at high concentrations of lead contamination in comparison to the control group. Similar to the current research, a significant rise was observed by Guardiola et al. (2015), in the alkaline phosphatase of Sparus aurata mucus exposed to varying concentrations of heavy metals and different exposure times. The increase of these enzymes in the mucus might be due to accumulation of Rudlet cells in the epithelium because of the stress resulting from exposure to heavy metals (Guardiola et al., 2015, Omidi et al., 2020).

Heat shock proteins are essential for maintaining the major functions of cells (Fink, 1994). The amount of heat-shock protein synthesis in response to oxidative stress conditions has been reported for different species (Hassanein et al., 1999; Rhee et al., 2009; Monari et al., 2011; Jiang et al., 2012; Simpkins et al., 2013; Xing et al., 2013). Indeed, various stressors induce the synthesis of these proteins (Sanders, 1993). Liver and gill tissues are selected as specific organs for the study of hsp70 gene expression due to their high susceptibility to contamination, which results in impaired cellular processes in these tissues (Rao et al., 2003; Safari et al., 2014).

In the present study, the relative expression levels of hsp70 gene increased under the influence of lead contaminant (at $7.5 \%$ \& $30 \%$ LC50), compared to the control group. Similarly, Safari et al. (2014) found a significant increase in hsp70 gene expression level in the liver of Acipenser persicus exposed to cadmium chloride. In addition, Shabrangharehdasht et al. (2020) reported a significant growth in hsp70 expression level in Oncorhynchus mykiss exposed to different nanosilver concentrations. Hsp70 gene expression levels in the gill showed no significant difference, which concurs with the study of Osman et al. (2019), who explored the lead (II) nitrate impact on the levels of hsp70 expression. The difference in the amount of synthesis across various tissues can be attributed to the inherent differences between the tissues (Safari et al., 2014; Shabrangharehdasht et al., 2020).

\section{Conclusions}

Our results indicated the positive impact of lead contamination on the expression of gene hsp70 in the liver. The results also indicated that there are differences between the mucus protein pattern of treated group and the control group. Further, of the innate mucus immune parameters, alkaline phosphatase and protein levels indicated a significant rise in concentrations of lead in comparison with the 

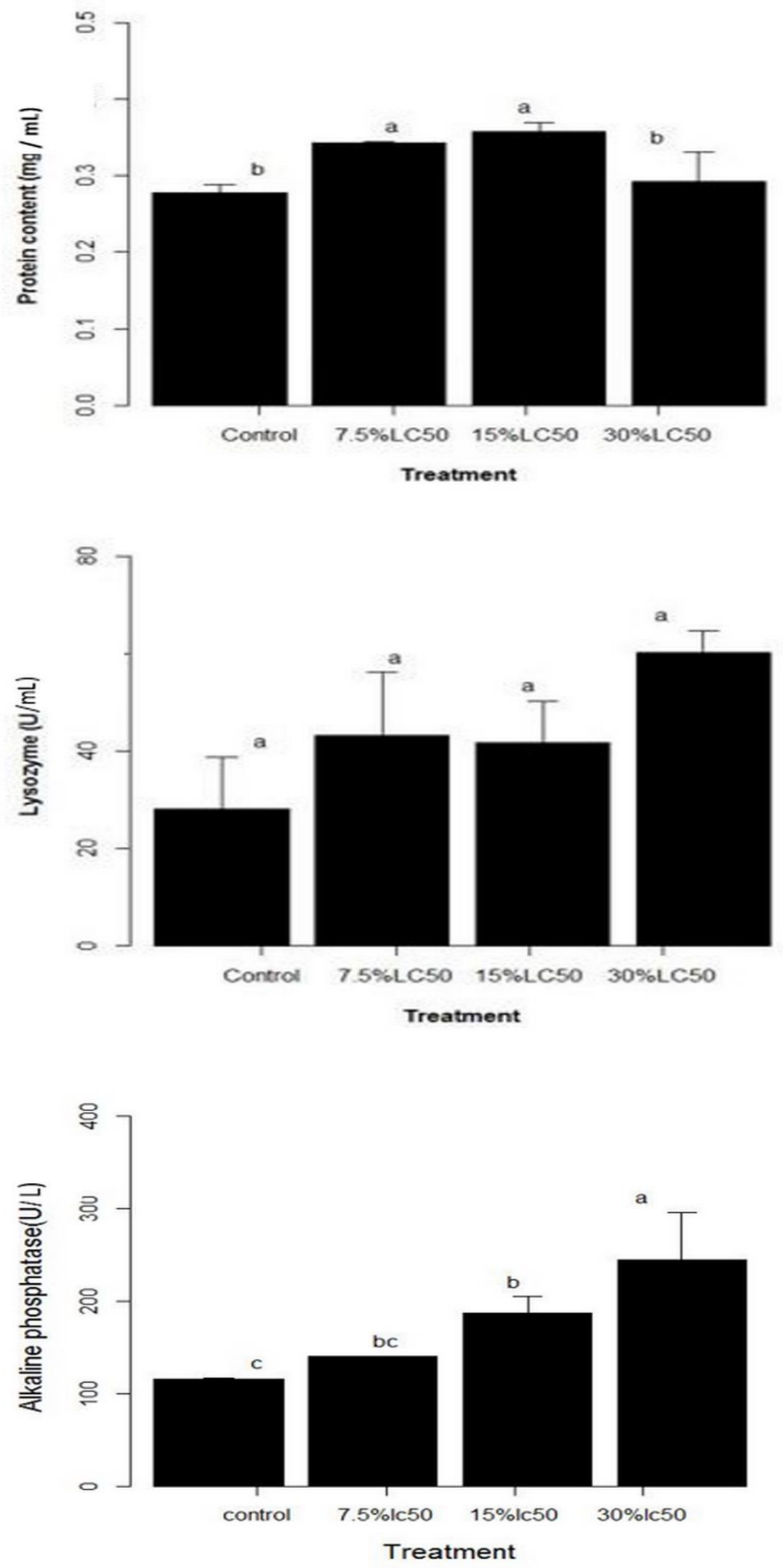

Figure. 5. Levels of mucus safety parameters in Common carp exposed to lead; Values are expressed as the mean \pm S.D. The bars with different letters show significant differences between treatments $(P<0.05)$. 
control group. According to the results mentioned, mRNA-hsp70 and mucosal indicators can be considered sensitive biochemical indicators in Cyprinus carpio for ecotoxicological research.

\section{Ethical Statement}

This study was carried out in strict accordance with the recommendations in the Guide for the Care and Use of Laboratory Animals of the National Institutes of Health. The protocol was approved by the Committee on the Ethics of Animal Experiments of the Central Fisheries Research Institute (SUMAE) (Protocol Number: 27-2956). All efforts were made to minimize suffering.

The scientific and ethical responsibility of the animal experiment belongs to the author(s).

The editor has the right to reject manuscripts on suspicion of aforementioned requirements; animal welfare and/or lack of ethics committee reports.

\section{Funding Information}

The author(s) received no specific funding for this work.

\section{Author Contribution}

FO: Investigation, Writing - Review \& Editing. HJ: Supervision. RP: Formal Analysis. $\mathrm{MH}$ : Project Administration. HP: Conceptualization, Methodology, Resources.

\section{Conflict of Interest}

The author(s) declare that they have no known competing financial or non-financial, professional, or personal conflicts that could have appeared to influence the work reported in this paper.

\section{Acknowledgements}

The staff at the Aquaculture laboratory of the department of fisheries, Gorgan University of agricultural science and natural resources are highly appreciated for their assistance.

\section{References}

Cantinha, R.D.S., Borrely, S.I., Oguiura, N., Pereira, C.A.D.B., Rigolon, M.M. \& Nakano, E. (2017). HSP70 expression in Biomphalaria glabrata snails exposed to cadmium. Ecotoxicology and Environmental Safety, 140 17-23, https://doi.org/10.1016/j.ecoenv.2017.02.026

Chong, K., Joshi, S., Jin, L.T., Shu-Chien, A.C. (2006). Proteomics profiling of epidermal mucus secretion of a cichlid (Symphysodon aequifasciata) demonstrating parental care behavior. Proteomics, 6, 22512258.https://doi.org/10.1002/pmic.200500591

Dautremepuits, C., Paris-Palacios, S., Betoulle, S. \& Vernet, G. (2004). Modulation in hepatic and head kidney parameters of carp (Cyprinus carpio L.) induced by copper and chitosan. Comparative Biochemistry and Physiology Part C, 137, 325-333. https://doi.org/10.1016/j.cca.2004.03.005

Ebran, N., Julien, S., Orange, N., Saglio, P., Lemaître, C. \& Molle, G. (1999). Pore-forming properties and antibacterial activity of proteins extracted from epidermal mucus of fish. Comparative Biochemistry and Physiology Part A, 122, 181-189.

https://doi.org/10.1016/S1095-6433(98)10165-4

Ellis, A.E. (2001). Innate host defense mechanisms of fish against viruses and bacteria. Developmental and Comparative Immunology, 25, 827-839, https://doi.org/10.1016/S0145-305X(01)00038-6

Fagan, M.S., O'Byrne-Ring, N., Ryan, R., Cotter, D., Whelan, K. \& Mac Evilly, U. (2003). A biochemical study of mucus lysozyme proteins and plasma thyroxine of Atlantic salmon (Salmo salar) during smoltification. Aquaculture, 222, 287-300. https://doi.org/10.1016/S0044-8486(03)00128-5

Fink, A.L. (1999). Chaperone-mediated protein folding. Physiological Reviews, 79 425-449, https://doi.org/10.1152/physrev.1999.79.2.425

Guardiola, F.A., Dioguardi, M., Parisi, M.G., Trapani, M.R., Meseguer, J., Cuesta, A. \& et al. (2015). Evaluation of waterborne exposure to heavy metals in innate immune defences present on skin mucus of gilthead seabream (Sparus aurata). Fish and Shellfish Immunology, 45, 112123. https://doi.org/10.1016/j.fsi.2015.02.010

Hassanein, H.M.A., Banhawy, M.A., Soleiman, F.M., AbdelRehim, S.A., Muller, W.E.G. \& Schroder, H.C. (1999). Induction of hsp70 by the herbicide oxyfluorfen (Goal) in the Egyptian Nile Fish, Oreochromis niloticus. Archives of Environmental Contamination and Toxicology, 37, 78-84. https://pubmed.ncbi.nlm.nih.gov/10341045/

Head, J.A., Dolinoy, D.C. \& Basu, N. (2012). Epigenetics for ecotoxicologists. Environmental Toxicology and Chemistry, 31, 221-227. https://doi.org/10.1002/etc.1707

Heidary, S., Hajimoradloo, A., Banai, A., Aghamaali, M. \& Gorbani, R. (2016). Changes in biochemical and physiological responses of common carp, Cyprinus carpio L. after long-term exposure to $\mathrm{Pb}$ (II). Caspian Journal of Environmental Sciences 14, 311-320. https://cjes.guilan.ac.ir/article_2073.html

Iger, Y., Jenner, H.A. \& Bonga, S.E. (1994). Cellular responses in the skin of the trout (Oncorhynchus mykiss) exposed to temperature elevation. Journal of Fish Biology, 44, 921-935. https://doi.org/10.1111/j.1095-8649.1994.tb01265.x

Jiang, J., Shi, Y., Shan, Z., Yang, L., Wang, X. \& Shi, L. (2012). Bioaccumulation, oxidative stress and hsp70 expression in Cyprinus carpio L. exposed to microcystin-LR under laboratory conditions. Comparative Biochemistry and Physiology Part C, 155, 483-490. https://doi.org/10.1016/j.cbpc.2011.12.008

Khattab, S., El Sherif, F., El-Garhy, H.A, Ahmed, S. \& Ibrahim, A. (2014). Genetic and phytochemical analysis of the in vitro regenerated Pilosocereus robinii by ISSR, SDS-PAGE and HPLC. Gene, 533, 313-321. https://doi.org/10.1016/j.gene.2013.09.026

Laemmli, U.K. (1970). Cleavage of structural proteins during the assembly of the head of bacteriophage T4. Nature, 227, 680-685.https://doi.org/10.1038/227680a0 
Livak, K.J. \& Schmittgen, T.D. (2001). Analysis of relative gene expression data using real-time quantitative PCR and the 2- $\triangle \triangle C T$ method. Methods, 25, 402-408. https://doi.org/10.1006/meth.2001.1262

Lortal, S., Valence, F., Bizet, C. \& Maubois, J.L. (1997). Electrophoretic pattern of peptidoglycan hydrolases, a new tool for bacterial species identification: application to 10 Lactobacillus species. Research in Microbiology, 148, 461-474. https://doi.org/10.1016/S0923-2508(97)88344-1

Lowry, O.H., Rosebrough, N.J., Farr, A.L. \& Randall, R.J. (1951). Protein measurement with the folin phenol reagent. Journal of Biological Chemistry, 193 265-275. https://pubmed.ncbi.nlm.nih.gov/14907713/

Miandare, H.K., Farahmand, H., Akbarzadeh, A., Ramezanpour, S., Kaiya, H., Miyazato, M., Rytkönen, K.T. \& Nikinmaa, M. (2013). Developmental transcription of genes putatively associated with growth in two sturgeon species of different growth rate, General and Comparative Endocrinology, 182, 41-47. https://doi.org/10.1016/j.ygcen.2012.11.013

Monari, M., Foschi, J., Rosmini, R., Marin, M.G. \& Serrazanetti, G.P. (2011). Heat shock protein 70 response to physical and chemical stress in Chamelea gallina. Journal of Experimental Marine Biology and Ecology, 397, 71-78. https://doi.org/10.1016/j.jembe.2010.11.016

Omidi, F., Jafaryan, H., Patimar, R., Harsij, M. \& Paknejad, H. (2020). Biochemical biomarkers of skin mucus in Neogobius melanostomus for assessing lead pollution in the Gulf of Gorgan (Iran). Toxicology Reports, 7, 109-117. https://doi.org/10.1016/j.toxrep.2019.12.003

Osman, A.G.M., Wuertz, S. \& Mohammed-Geba, K. (2019). Lead-induced heat shock protein (HSP70) and metallothionein (MT) gene expression in the embryos of African catfish Clarias gariepinus (Burchell, 1822). Scientific African, 3, e00056. https://doi.org/10.1016/j.sciaf.2019.e00056

Ouellet, V., Pierron, F., Mingelbier, M., Fournier, M., Fournier, M. \& Couture, P. (2013). Thermal stress effects on gene expression and phagocytosis in the common carp (Cyprinus Carpio): A Better Understanding of the Summer 2001 st. Lawrence river fish kill. Fisheries Science, 6, 99-106. https://benthamopen.com/ABSTRACT/TOFISHSJ-6-99

Panigrahi, A., Viswanath, K. \& Satoh, S. (2011). Real-time quantification of the immune gene expression in rainbow trout fed different forms of probiotic bacteria Lactobacillus rhamnosus. Aquaculture Research, 42, 906-917. https://doi.org/10.1111/j.1365-2109.2010.02633.x

Pottinger, T.G. \& Pickering, A.L. (1985). The effects of 11ketotestosterone and testosterone on the skin structure of Brown Trout, Salmo trutta L. General and Comparative Endocrinology, 59, 335-342. https://doi.org/10.1016/0016-6480(85)90389-2

Radonic, A., Thulke, S., Mackay, I.M., Landt, O., Siegert, W. \& Nitsche, A. (2004). Guideline to reference gene selection for quantitative real-time PCR. Biochemical and Biophysical Research Communications, 313, 856-862. https://doi.org/10.1016/j.bbrc.2003.11.177

Rao, J.V., Rani, C.H.S., Kavitha, P., Rao, R.N. \& Madhavendra, S.S. (2003). Toxicocity of chlorpyrifos to the fish Oreochromis mossambicus. Bulletin of Environmental contamination and Toxicology, 70, 985-992. https://doi.org/10.1007/s00128-003-0079-0
Rhee, J.S., Raisuddin, S.K., Lee, W., Seo, J.S., Ki, J.S., Kim, I.I.C., Parkd, H.G. \& Lee, J.S. (2009). Heat shock protein (Hsp) gene responses of intertidal copepod Tigriopus japonicus to environmental toxicants. Comparative Biochemistry and Physiology Part C, 149, 104-112. https://doi.org/10.1016/j.cbpc.2008.07.009

Rose, W.L., Nisbet, R.M., Green, P.G., Norris, S., Fan, T., Smith, E.H., Cherr, G.N. \& et al. (2006). Using an integrated approach to link biomarker responses and physiological stress to growth impairment of cadmium exposed larval topsmelt. Aquatic Toxicology, 80, 298-308. https://doi.org/10.1016/j.aquatox.2006.09.007

Ross, N.W., Firth, K.J., Wang, A., Burka, J.F. \& Johnson, S.C. (2000). Change in hydrolytic enzyme activities of naïve Atlantic salmon (Salmo salar) skin mucus due to infection with the salmon louse (Lepeophtheirus salmonis) and cortisol implantation. Diseases of aquatic organisms, 41, 43-51. https://pubmed.ncbi.nlm.nih.gov/10907138/

Safari, R., Shabani, A., Ramezanpour, S., Imanpour, M.R. \& Rezvani, S. (2014). Alternations of heat shock proteins (hsp70) gene expression in liver and gill of Persian sturgeon (Acipenser persicus Borodin, 1987) exposed to cadmium chloride. Iranian journal of fisheries sciences, 3,979-997. http://jifro.ir/browse.php?a_id=1795\&sid=1\&slc_lang= en

Sanders, B.M. (1993). Stress proteins in aquatic organisms: an environmental perspective. Critical Reviews in Toxicology, 23 49-75. https://doi.org/10.3109/10408449309104074

Shabrangharehdasht, M., Mirvaghefi, A. \& Farahmand, H. (2020). Effects of nanosilver on hematologic, histologic and molecular parameters of rainbow trout (Oncorhynchus mykiss). Aquatic Toxicology, 225, 105549.https://doi.org/10.1016/j.aquatox.2020.105549

Sheikhzadeh, N., Pashaki, A.K., Nofouzi, K., Heidarieh, M. \& Tayefi-Nasrabadi, H. (2012). Effects of dietary Ergosan on cutaneous mucosal immune response in rainbow trout (Oncorhynchus mykiss). Fish Shellfish immunology, 32, 407-410. https://doi.org/10.1016/j.fsi.2011.11.028

Simpkins, A.M., Tatum, T.E., Cardin, D.L. \& Wolf, W.C. (2013). Metallothionein and heat-shock protein 70 induction in caged and wild fathead minnows (Pimephales promelas) exposed to the Ouachita River, Louisiana. Journal of Toxicology and Environmental Health, 76, 98-106. https://doi.org/10.1080/15287394.2013.738174

Subramanian, S., MacKinnon, SH.L. \& Ross, N, W. (2007). A comparative study on innate immune parameters in the epidermal mucus of various fish species. Comparative Biochemistry and Physiology Part B, 148, 256-263. https://doi.org/10.1016/j.cbpb.2007.06.003

Subramanian, S., Ross, N.W. \& MacKinnon, SH.L. (2008). Comparison of antimicrobial activity in the epidermal mucus extracts of fish. Comp. Comparative Biochemistry and Physiology B, 150, 85-92. https://doi.org/10.1016/j.cbpb.2008.01.011

Tedeschi, J.N., Kennington, W.J., Berry, O., Whithing, S., Meekan, M. \& Mitchell, N.J. (2015). Increased expression of HSP70 and HSP70 mRNA as biomarkers of thermal stress in loggerhead turtle embryos (Caretta caretta). Journal of Thermal Biology, 47, 42-50. https://doi.org/10.1016/j.jtherbio.2014.11.006

Timalata, K., Marimuthu, K., VengkadesRao, R., Xavier, R., Rahman, M.A., Sreeramanan, S., Arasu, M.V., Al-Dhabi, 
N.A. \& Arockiaraj, J. (2015). Elucidation of innate immune components in the epidermal mucus of different freshwater fish species. Acta Ichthyologica et Piscatoria, 45,221-230.

https://www.researchgate.net/publication/283575021_Elu cidation_of_innate_immune_components_in_the_epider mal_mucus_of_different_freshwater_fish_species

Vinodhini, R. \& Narayanan, M. (2008). Bioaccumulation of heavy metals in organs of fresh water fish Cyprinus carpio (Common carp). International Journal of Environmental Science and Technology, 5, 179-182. https://doi.org/10.1007/BF03326011

Xing, H., Li, S., Wang, X., Gao, X., Xu, S. \& Wang, X. (2013). Effects of atrazine and chlorpyrifos on the mRNA levels of HSP7O and HSC70 in the liver, brain, kidney and gill of common carp (Cyprinus carpio L.). Chemosphere, 90,
910-916.

https://doi.org/10.1016/j.chemosphere.2012.06.028

Yokoyama, S., Koshio, S., Takakura, N., Oshida, K., Ishikawa, M., Gallardo-Cigarroa, F.J., Catacutan, M.R. \& Teshima, S.I. (2006). Effect of dietary bovine lactoferrin on growth response, tolerance to air exposure and low salinity stress conditions in orange spotted grouper Epinephelus coioides. Aquaculture, 255, 507-513. https://doi.org/10.1016/j.aquaculture.2005.12.001

Zhang, X., Yang, F., Zhang, X., Liao, T., Song, S. \& Wang, J. (2008). Induction of hepatic enzymes and oxidative stress in Chinese rare minnow (Gobio cyprisrarus) exposed to waterborne hexabromocyclododecane (HBCDD). Aquatic Toxicology, 86, 4-11. https://doi.org/10.1016/j.aquatox.2007.07.002 